\title{
Associated Health Risks from Heavy Metal-Laden Effluent into Point Drainage Channels in Faisalabad, Pakistan
}

\section{Taqi Raza ${ }^{*}$, Kashif Nazir Qureshi², Shakeel Imran ${ }^{2}$, Neal Samuel Eash ${ }^{3}$ and Imma Bortone ${ }^{4}$}

${ }^{1}$ Land Resources Research Institute, NARC, Islamabad-45500, Pakistan; ${ }^{2}$ University of Agriculture Faisalabad, UAF SubCampus Burewala-61010, Pakistan; ${ }^{3}$ Biosystems Engineering and Soil Science, The University of Tennessee, USA; ${ }^{4}$ School of Water, Energy and Environment, Cranfield University UK.

Abstract | Industrial effluent discharge has increased due to rapid urbanization and industrialization. Irrational use of this water for irrigation has caused environmental and health issues. The objective of the current study is to evaluate the treated effluents of textile, ghee and chemical industries for major heavy metals $(\mathrm{Cd}, \mathrm{Cr}, \mathrm{Ni}, \mathrm{Pb}$ and $\mathrm{Fe}$ ) and other basic analysis (pH, EC, TSS and TDS). Effluent samples were collected from the discharge of industries entering into main wastewater collecting channel located in Faisalabad city. Heavy metals contents were determined via atomic absorption spectrophotometry. Results showed that the highest $\mathrm{pH}(11.06)$ was recorded in textile effluent while EC $(7.89 \mathrm{mS} / \mathrm{cm})$, TSS $(1185.55 \mathrm{mg} / \mathrm{L})$ and TDS $(6317.33 \mathrm{mg} / \mathrm{L})$ were found highest in chemical industrial effluents. Heavy metals contents were determined through atomic absorption spectrophotometer. The mean comparison of heavy metal concentration $(\mathrm{mg} / \mathrm{L})$ showed the concentration of $\mathrm{Cd}, \mathrm{Cr}$ and $\mathrm{Ni}$ were within the safe limits; however, $\mathrm{Fe}$ and $\mathrm{Pb}$ were higher than the safe limits in all industrial effluents. The highest/unsafe concentration of metal Fe was recorded 4.093, 2.979 and $2.959 \mathrm{mg} / \mathrm{L}$ in the effluents of chemical, textile and ghee mill respectively. While the highest/ unsafe concentration of metal $\mathrm{Pb}$ was recorded $0.643,0.578$ and $0.286 \mathrm{mg} / \mathrm{L}$ in the effluents of textile, chemical and ghee mill respectively. The permissible limits of heavy metals $\mathrm{Fe}$ and $\mathrm{Pb}$ is 0.5 and $2 \mathrm{mg} / \mathrm{L}$ respectively. We conclude that before discharge into a receiving stream, the effluents must be treated more time with a treatment method that removes $\mathrm{Pb}$ and $\mathrm{Fe}$ within standard limits else the discharge will pose pollution and health risks to human beings.

Received | April 19,2021; Accepted | June 13, 2021; Published | June 20, 2021

*Correspondence | Taqi Raza, Land Resources Research Institute, NARC, Islamabad-45500, Pakistan; Email: taqiraza85@gmail.com

Citation | Raza, T., K.N. Qureshi, S. Imran, N.S. Eash and I. Bortone. 2021. Associated health risks from heavy metal-laden effluent into point drainage channels in Faisalabad, Pakistan. Pakistan Journal of Agricultural Research, 34(3): 487-494.

DOI | https://dx.doi.org/10.17582/journal.pjar/2021/34.3.487.494

Keywords | Atomic absorption spectrophotometer, Faisalabad, Pakistan, Heavy metals, Health risks, Industrial effluents

\section{Introduction}

Olobally, it has been recognized that water

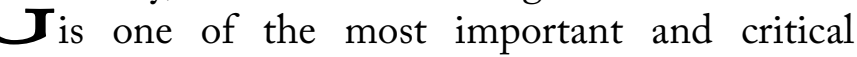
natural resources to sustain life on this earth. Water composition is continuously changing due to natural and anthropogenic activities that ultimately cause environmental pollution (Yousaf et al., 2016). These pollutants include both chemical (Heavy metals, detergents, agrochemical residues, hydrocarbons etc.) and microbial (Bacteria, protozoa, virus, fungi etc.) pollutants from human and animal fecal waste which can be lethal to humans (Yi et al., 2011). Sedimentation of microorganisms into dissolved organic contents present in the wastewater through biological treatments considered the best approach to remove the microbial pollutants. It serves as that are substrates for the living organism present in the water 
(Gunatilake, 2015). Heavy metal contamination is the most important and widespread environmental issue all over the world. Among all the issues either natural or anthropogenic, entry of toxic elements from industrial wastewater is considered the major source for contamination in a natural reservoir of water (Simonetti et al., 2019). Naturally, the concentration of heavy metals varies by source.

However, most heavy metals cause serious toxicity when present even in low concentration (Simeonov et al., 2010). The accumulation of heavy metals in the human body through direct or indirect uptake cause detrimental issues for human health (Titilawo et al., 2018). The health effect of the heavy metal varies and depend on the type of metal, concentration and nature and exposure of ions. Some of the heavy metals cause carcinogenic effects and another cause teratogen/ mutagen effect on human and animal. Heavy metals which are considered primarily important in causing environmental toxicity include $\mathrm{As}, \mathrm{Cr}, \mathrm{Cd}, \mathrm{Pb}, \mathrm{Ni}$, $\mathrm{Mn}, \mathrm{Hg}, \mathrm{Cu}$ and $\mathrm{Zn}$ (Ali and Ilahi, 2019). Heavy metal pollution is reported as a global level concern but the contamination intensity varies by country. The entry of municipal, industrial and agricultural discharge into the canal and river is considered the main point source of heavy metals into water resources (Manoj et al., 2012). A number of studies in Punjab especially in Lahore, Karachi, Faisalabad and many other cities of Pakistan, have documented the soil and water contamination due to heavy metals. Faisalabad (Lyallpur) is the $3^{\text {rd }}$ largest and well-known industrial city of Pakistan and quoted as the Manchester of Pakistan. Farmers communities use discharge of these industries directly or indirectly for irrigation purpose. The farmers consider the discharge of industries as the cheapest source of irrigation water and the richest source of nutrients especially for vegetable fields to compensate for the nutrient requirement of the plant. Even industrial wastewater is the best alternative water source but also can have a harmful effect on crop and soil due to heavy metal pollution and resulting public health concerns (Li et al., 2019). Prior studies of industrial wastewater discharge in Faisalabad based upon chemical, biological, and physical parameters suggested that heavy metal accumulation in plants posed an indirect threat to humans. These studies were conducted on the wastewater that has direct entry into canal water. Regarding the environmental concern of industrial effluents, a study was designed to analyze the heavy metals $(\mathrm{Cd}, \mathrm{Cr}, \mathrm{Ni}, \mathrm{Pb}$ and $\mathrm{Fe}$ ) in one time treated wastewater from textile, ghee and chemical industries located in Faisalabad and estimate possible associated health risks.

\section{Materials and Methods}

\section{Study area}

For the current study, the industrial zone of Faisalabad, Pakistan was selected. The Faisalabad city is located $31.20^{\circ}$ in North and $73.30^{\circ}$ in East of Pakistan. The effluents of three important industries including textile (Al-Farid Fabrics Pvt. Ltd), ghee mill (Madni Ghee Mill Pvt. Ltd) and chemical (Sitara chemical Mill Pvt. Ltd) has been investigated in the current study for chemical $\{\mathrm{pH}, \mathrm{EC}$ (Electric Conductivity), TSS (Total Suspended Salts) and TDS (Total Dissolved Salts) $\}$ parameters as well as for heavy metal $(\mathrm{Cd}, \mathrm{Cr}$, $\mathrm{Ni}, \mathrm{Pb}$ and $\mathrm{Fe}$ ). Furthermore, these industrial effluents were evaluated for health risk assessment on the basis of heavy metals concentration.

\section{Sample collection and preparation}

In February 2019 we conducted a survey of Faisalabad city to differentiate and evaluate wastewater production from different industries. Among the industries, chemical, ghee and textile industries were selected for the evaluation of heavy metals and associated health risk. During the month of March 2019, three samples were taken from the same industrial wastewater outlet which was treated one time before entry into the main drainage. Three effluents samples were taken 3 hours apart from each industry point outlet into the main channel and stored in a $1 \mathrm{~L}$ little plastic bottle. These bottles were stored on ice. Before the sampling, the bottle was washed 10 times diluted sulfuric acid and rinsed with distilled water and dried in the oven for 3-4 hours at $25^{\circ} \mathrm{C}$. Water samples were filtered using Whatman Number 40 and analyzed by technique of Flame Atomic Absorption Spectrophotometer.

\section{Instrumental analysis}

A technique of Atomic AbsorptionSpectrophotometer with 300 analysts of Atomic Absorption Spectrophotometer was used for quantification of desire heavy metals $(\mathrm{Cd}, \mathrm{Cr}, \mathrm{Pb}, \mathrm{Ni}$ and $\mathrm{Fe})$ with suitable Perkin Elmer (Cathode) lamp (Delves, 1971 \#272). As a part, graphite furnace is connected with the AAS system for the analysis of desired heavy metals and a computer is attached for the quantification of every metallic element. A burner of acetylene with air equipped was used to control the rate of airflow. For 
preparation and analysis of the sample, an analytical grade with $99.0 \%$ purity chemicals was used. For $\mathrm{Cd}$ and $\mathrm{Fe}$ quantification, the standards $(2,4,6$ and 8 $\left.\mathrm{mgL}^{-1}\right)$ were used with $\mathrm{Cd}$-cathode and $\mathrm{Fe}$-cathode lamp respectively. Similarly, for the quantification of the $\mathrm{Ni}, \mathrm{Zn}$ and $\mathrm{Pb}$ metals the standards $(0.5,1$, 1.5, $\left.3 \mathrm{mgL}^{-1}\right),\left(0.4,0.6,0.8\right.$ and $\left.1 \mathrm{mgL}^{-1}\right)$ and $(1,2,3$ and $\left.4 \mathrm{mgL}^{-1}\right)$ were used respectively with respective cathode lamp. The concentration of a metal element in the desired sample and distal water were estimated through the extrapolation of the curve prepared on the computer. The value of the blank sample was subtracted from all of the samples to reduce the chances of error attributed due to the presence of regent impurities that were used for analysis during the experiment. The samples of each discharge were analyzed and the average was taken.

\section{Health risk assessment}

There are a number of ways to assess the potential health risks associated with human exposure to toxic chemicals presence in the environment, such as identification and exposure to hazard, risk and exposure assessment (Tepanosyan et al., 2017). However, the health risk associated with dangerous heavy metals in the effluents collected from the three different industrial discharge located in Faisalabad city were estimated through dermal contact and ingestion using the criterial method for health risk given by the (USEPA, 1995). However, in the current work, the health risk associated with heavy metals present in the effluents was assessed on the basis of heavy metal concentrations in comparison to permissible limits of heavy metals given by the USEPA. As the concentration of heavy metals increases from the toxic limit, it pollutes channel water that is ultimately discharge into a receiving canal. The use of this water for any purpose whether for irrigation or animal/ human drinking or entry into groundwater through different process cause water pollution will ultimately lead to health risks for the living organism.

\section{Statistical analysis}

Chemical properties and heavy metal contents of industrial wastewater were analyzed statistically using Statistix 8.1. ((Statistix Inc., Florida, USA). Statistically, significant difference (SD) among the mean concentration of heavy metal in different industrial effluents was calculated using multivariate Tukey test. Results were present in the Table 1.

\section{Results and Discussion}

Effluents samples were analyzed for Physio-chemical characteristic and heavy metals concentration and the results were compared with the standard set by the WHO (World Health Organization) and NEQS (National Environmental Quality Standard). Electric conductivity (EC) and $\mathrm{pH}$ limits are important parameters that must be followed. Conductivity defines the ability of water to conduct electricity and it depends on the availability of ions in water. In the current study, the $\mathrm{pH}$ of industrial effluents varied between 8.0 to 11.06 and the maximum $\mathrm{pH}$ $(11.06 \pm 0.02)$ was recorded in the textile effluents. The $\mathrm{pH}$ of ghee and chemical industrial effluents was found lower at 8.00 and 9.73 respectively as compared to textile effluents. Except for the $\mathrm{pH}$ of Ghee effluent, the other industrial effluent $\mathrm{pH}$ was recorded out of the permissible range set by the WHO for the $\mathrm{pH}$ is 6-8.5 (WHO, 1993). The quality of water also directly related to conductivity and any changes in it also change the quality of water. In the given study, the $\mathrm{EC}(\mathrm{mS} / \mathrm{cm})$ varied from 2.40 to 7.98 among the industrial effluents. However, the maximum EC was recorded in the effluent of the chemical industry $(7.89 \pm 1.069)$ and the minimum in effluents of the ghee industry $(2.40 \pm 0.798)$. Similarly, the EC of the textile industry was recorded $(3.21 \pm 2.63)$. The $\mathrm{pH}$ and $\mathrm{EC}$ of the water affected by the water composition (salts, heavy metals, temperature etc.). The chemical and textile industrial effluents have greater $\mathrm{pH}$ and $\mathrm{EC}$ because these waters contain a high concentration of salts and metals (Aboulhassan et al., 2006; Olugbuyiro, 2011). Similarly, in these industries common heating and chemical reactions create an alkaline environment. Thus, these industries have a strongly alkaline $\mathrm{pH}$. Similar results were found in another study conducted on textile and chemical industrial wastewater and concluded moderate to strong alkaline water of these industries (Ali et al., 2006; Shah et al., 2015). However, most of the studies showed that the ghee and oil industrial effluents have less $\mathrm{pH}$ and $\mathrm{EC}$ as compared to the chemical and textile industries. Other industrial effluents contained less concentration of metals, salts and other chemicals that increase reaction rate in water and increased the $\mathrm{pH}$ and $\mathrm{EC}$. Thus, Ghee industrial effluents have low $\mathrm{pH}$ and $\mathrm{EC}$ as compared to other industries (Afzal et al., 2014). 
Table 1: Mean value of physico-chemical properties of different industrial effuents against permissible limits by WHO.

$\begin{array}{llllll}\text { Parameters } & \text { Permissible limits } & \text { Unit } & \text { Chemical industry } & \text { Ghee mill } & \text { Textile industry } \\ \text { pH } & 6 \text { to } 8.5 & --- & 9.73 \pm 0.26 & 8.00 \pm 0.12 & 11.06 \pm 0.02 \\ \text { EC } & >4 & \mathrm{mS} / \mathrm{cm} & 7.89 \pm 1.069 & 2.40 \pm 0.798 & 3.21 \pm 2.63 \\ \text { TSS } & >400 & \mathrm{mg} / \mathrm{L} & 1185.55 \pm 0.975 & 361.005 \pm 0.295 & 490.35 \pm 0.396 \\ \text { TDS } & >3500 & \mathrm{mg} / \mathrm{L} & 6317.333 \pm 0.180 & 1540.267 \pm 0.197 & 2015.679 \pm 0.992\end{array}$

Table 2: Mean concentration of heavy metals in different industrial effuents against permissible limits by WHO.

$\begin{array}{llllll}\text { Heavy metals } & \mathbf{C d} & \mathbf{C r} & \mathbf{N i} & \mathbf{P b} & \mathbf{F e} \\ \text { Unit } & \mathrm{mg} / \mathrm{L} & & & & \\ \text { Permissible Limits } & 0.1 & 1 & 1 & 0.5 & 2 \\ \text { Textile Industry } & 0.030 \pm 0.004 \mathrm{~b} & 0.241 \pm 0.027 \mathrm{c} & 0.760 \pm 0.044 \mathrm{a} & 0.634 \pm 0.048 \mathrm{a} & 2.979 \pm 0.071 \mathrm{~b} \\ \text { Ghee Mill } & 0.036 \pm 0.003 \mathrm{~b} & 0.667 \pm 0.017 \mathrm{a} & 0.246 \pm 0.029 \mathrm{c} & 0.286 \pm 0.020 \mathrm{c} & 2.959 \pm 0.103 \mathrm{~b} \\ \text { Chemical Industry } & 0.086 \pm 0.002 \mathrm{a} & 0.384 \pm 0.004 \mathrm{~b} & 0.640 \pm 0.037 \mathrm{~b} & 0.578 \pm 0.032 \mathrm{~b} & 4.093 \pm 0.335 \mathrm{a}\end{array}$

Higher $\mathrm{pH}$ and EC affect water quality and impacts aquatic macro organisms and microorganisms abundance and health (Shu et al., 2015; Ouyang et al., 2019). Total suspended solids (TSS) and total dissolved solids (TDS) are also two important water quality parameters. Total suspended solids (TSS) is the mixture of solid that are not dissolved in water and stay suspended in water making it an important parameter of water quality. TDS consists of a large number of inorganic salts and a small portion of organic matter. Likewise, TDS and TSS also varied from industry to industry. In the current study, TSS $(\mathrm{mg} / \mathrm{L})$ trend was found as the maximum TSS $(1185.55 \pm 0.975)$ in chemical effluents and minimum TSS (361.005 $\pm 0.295)$ in Ghee industrial effluents. While the TSS of textile industrial effluents was recorded higher than ghee industrial effluent but lower than chemical industrial effluent which is $(490.35 \pm 0.396)$. The permissible limits for TDS is $3500 \mathrm{mg} / \mathrm{L}$ by set by WHO. The maximum TDS $(6317.333 \pm 0.180)$ was recorded in the chemical industrial effluents and the minimum $(1540.267 \pm 0.197)$ in the ghee industrial effluents. Similarly, the textile indusial effluents followed the chemical industrial effluents having TDS value is $(2015.679 \pm 0.992)$. Thus, it is concluded that chemical and textile industrial effluents have more TSS and TDS as compared to Ghee industrial effluent. A similar, result was reported in Islamabad Pakistan (Afzal et al., 2014) and in India (Ajmal and Khan, 1984) that supported Ghee industrial effluents have low TSS and TDS as compared to other industrial effluents. Results related to the analysis of desired heavy metals $(\mathrm{Cd}, \mathrm{Cr}, \mathrm{Pb}, \mathrm{Ni}$ and $\mathrm{Fe})$ in the different industrial effluents are mentioned in the Table 2. The number of heavy metals above the acceptable limits varied by industry and treatment processes. However, in all three industrial effluents, the amount of $\mathrm{Cd}$, $\mathrm{Cr}$, and $\mathrm{Ni}$ present were under the permissible limits established by the US-EPA (1995) for heavy metals while the concentration of $\mathrm{Pb}$ and $\mathrm{Fe}$ were recorded higher as compared to US-EPA, 1995. The mean concentration of $\mathrm{Cd}$ varied between 0.030 and 0.086 $\mathrm{mg} / \mathrm{L}$ and the concentration of $\mathrm{Cd}$ in textile, ghee and chemical industrial effluents was $(0.030 \pm 0.004)$, $(0.036 \pm 0.003)$ and $(0.086 \pm 0.002)$, respectively. However, in all industrial effluents, the $\mathrm{Cd}$ range was present below permissible limits of Cd $(1 \mathrm{mg} / \mathrm{L})$ according to WHO standards. While comparatively, the highest $\mathrm{Cd}$ concentration was found in the chemical industry but the mean $\mathrm{Cr}$ concentration varied among the different industrial effluents $(0.667$ $\pm 0.017),(0.384 \pm 0.004)$ and $(0.241 \pm 0.027)$ in ghee, chemical and textile industrial effluents, respectively. The concentration of $\mathrm{Cr}$ in ghee mill effluents was greater as compared to others industrial effluents. In all the effluents the concentration of $\mathrm{Cr}$ was below the permissible limits of WHO for $\mathrm{Cr}(1 \mathrm{mg} / \mathrm{L})$. In the case of $\mathrm{Ni}$ metal, the amount of $\mathrm{Ni}$ varied between $0.246 \mathrm{mg} / \mathrm{L}$ and $0.76 \mathrm{mg} / \mathrm{L}$ and higher $\mathrm{Ni}$ concentration was recorded in the textile industrial effluents. However, in all the industrial effluents the concentration of $\mathrm{Ni}$ was under the permissible limits set by the WHO for $\mathrm{Ni}(1 \mathrm{mg} / \mathrm{L})$ in wastewater. $\mathrm{Ni}$ concentration was $(0.760 \pm 0.044),(0.640 \pm 0.037)$ and $(0.246 \pm 0.029)$ in chemical, textile and ghee industrial effluents, respectively which is higher than 
the permissible limits for these metals. In the case of $\mathrm{Pb}$ metal, the highest concentration of $\mathrm{Pb}(0.634$ $\pm 0.048)$ was recorded in textile effluents which is higher than the WHO permissible limits (0.01 $\mathrm{mg} / \mathrm{L})$ in wastewater. The trend of $\mathrm{Pb}$ was $(0.634 \pm$ $0.048),(0.578 \pm 0.032)$ and $(0.286 \pm 0.020)$ in textile, chemical and ghee industrial effluents, respectively but in ghee effluents, the $\mathrm{Pb}$ concentration was below the permissible limits. Similarly, the concentration of Fe was $(4.093 \pm 0.335),(2.979 \pm 0.071)$ and $(2.959 \pm$ $0.103)$ in textile, chemical and ghee industrial effluents, respectively. In all effluents, the $\mathrm{Fe}$ concentration was found above the permissible limits set by WHO for $\mathrm{Fe}(2 \mathrm{mg} / \mathrm{L})$ in wastewater. However, the dangerous concentration of $\mathrm{Fe}$ was only found in the chemical industrial effluent $(4.093 \pm 0.335)$.
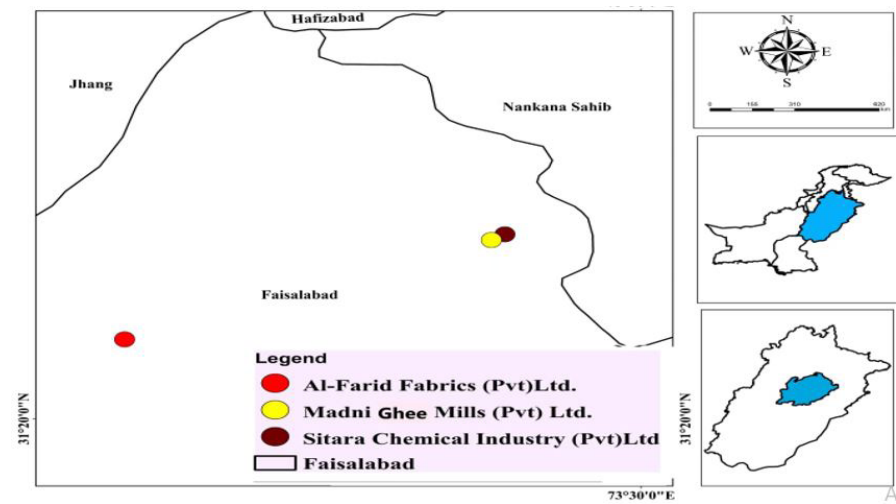

Figure 1: GIS map of industries under study located in Faisalabad.

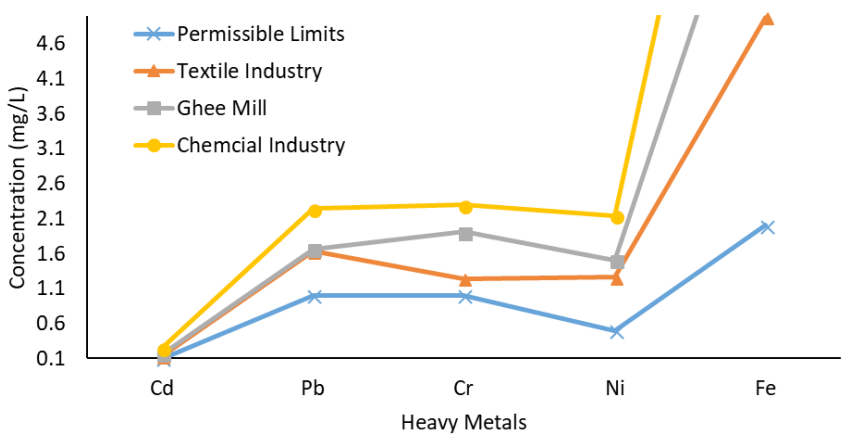

Figure 2: Heavy metals concentration in different industrial effuents in contrast of permissible limits.

Heavy metals by definition are considered toxic to humans and animals even at quite low concentration. Drinking water or eating foodstuff containing a high level of these metals can cause any number of health implications including severe stomach irritation, diarrhea and vomiting (Mahfooz et al., 2019). At higher doses, anemia can occur (Afzal et al., 2014). Even if heavy metal concentrations $(\mathrm{Cd}, \mathrm{Cr}$ and $\mathrm{Ni}$ ) are below the permissible limits for industrial effluents discharge, these toxins present both acute and chronic toxicity problems for humans (Iqbal et al., 2020). Children are especially vulnerable to heavy metal poisoning due to the chronic/continued effects of long-term exposure.

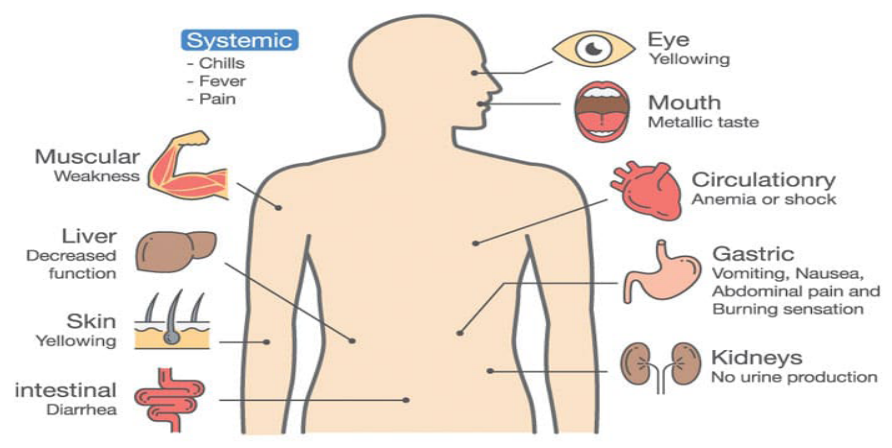

Figure 3: Heavy metals associated health risk in human being.

The wastewaters and their contaminants discharge into the Chenab River located at $30 \mathrm{~km}$ North West of Faisalabad, Pakistan where farmers pump it directly onto food crops directly as irrigation water (Abbas et al., 2017). Because of the linkage between surface water and groundwater, these same chemicals can also pollute groundwater and cause water-borne diseases (Shakoor and Farooq, 2013).

High Fe concentrations can cause a toxic effect on some organs such as skin is a trivial and hemosiderotic harmful effect on other organs as the liver can be affected (Jaishankar et al., 2014). Pb has a toxic effect on multiple body systems and is particularly harmful to young children (Sharma et al., 2016). High uptake of $\mathrm{Pb}$ is distributed to the brain, liver, kidney and bones. $\mathrm{Ni}$ impacts the central nervous and digestive system at high concentrations (Khan et al., 2008). Even lower concentration of heavy metals are considered very toxic for living organisms (Human, animal, aquatic organisms, microorganisms etc.) because many metals slowly accumulate in human tissue. Intake of heavy metals either by food or water increased the concentration of metals and caused severe itching and irritation in the stomach and resulted in diarrhoea and vomiting (Khan et al., 2013). Slightly, a higher concentration of $\mathrm{Pb}$ may cause a blood disorder anaemia in human by decreasing the time of reaction in human being (Ekeanyanwu et al., 2020).

From an environmental perspective, $\mathrm{Fe}$ and $\mathrm{Pb}$ are the most common existing heavy metals in the soil and water of urban area (Rahman and Singh, 2019). Principal sources of these two heavy metals including 
textile industries, chemical and dye industries, agrochemical industries and ghee mills (Jumbe and Nandini, 2009). The current study addressed that one time treated industrial effluents are still impacting water quality and will ultimately causing health risks for living organisms (Ekeanyanwu et al., 2020). Therefore, it is our responsibility to advocate the proper treatment for the different industrial effluents in order to protect our soil and water resource for all humankind.

\section{Conclusions and Recommendations}

In the current study, the chemical analysis showed that EC, TSS and TDS were higher in the effluents of the chemical industry except for $\mathrm{pH}$ which recorded higher in the textile industrial effluent. Similarly, the analysis of desire heavy metals in different industrial effluents shows that except $\mathrm{Pb}$ and $\mathrm{Fe}$, all other heavy metals are not exceeded the allowable limits. According to the analysis of heavy metals, the trend of heavy metals in textile effluents was followed as $\mathrm{Ni}>\mathrm{Cr}>\mathrm{Pb}>\mathrm{Cd}$, while in Ghee Mill as $\mathrm{Cr}>\mathrm{Ni}$ $>\mathrm{Cd}>\mathrm{Pb}$. Similarly, in chemical effluent, this trend was followed as $\mathrm{Ni}>\mathrm{Cr}>\mathrm{Pb}>\mathrm{Cd}$. We conclude that industrial effluents should be treated to remove the toxic heavy metals before discharge and should not be discharged if any pollutant is above the limits adopted by the USEPA and WHO. Due to harm the past discharges have done to receiving streams, an educational campaign is needed that specifies the health risks associated with direct contact with the canal receiving this toxic waste.

\section{Acknowledgments}

The authors are also very grateful to Fatimah Jinnah University Rawalpindi for provision of an Atomic Absorption Spectrophotometer for the analysis of heavy metals. The authors are also very thankful to Gajanan S Kothawade from Washington State University, USA for GIS mapping of the industrial zone of Faisalabad.

\section{Novelty Statement}

This study showed that one time treatment of industrial effluents is not enough. Industrial effluents should be treatment more than one time to maintain the quality of water before entry into main channel of water. More times treatment of water improves the quality of water and reduce the heavy metals pollution and health risks due to heavy metals.

\section{Author's Contribution}

TR and KNQ: The protocol and design of current study.

SI: Supervised and assist in statistical analysis. Involved in writing, editing, and revising the manuscript.

NSE and IB: They improved the quality, language and structure of the paper. They also support in manuscript processing charges.

\section{Conflict of interest}

The authors have declared no conflict of interest.

\section{References}

Abbas, Q. B. Yousaf, G. Liu, M. Zia-ur-Rehman, M.U. Ali, M.A.M. Munir and S.A. Hussain. 2017. Evaluating the health risks of potentially toxic elements through wheat consumption in multi-industrial metropolis of Faisalabad, Pakistan. Environ. Sci. Pollut. Res., 24(34): 26646-26657.https://doi.org/10.1007/s11356017-0311-9

Ali, S., R. Nadeem, H.N. Bhatti, S. Hayat, S. Ali, Chatha, S. and M. Muneer. 2006. Analyses and treatment of textile effluents. Int. J. Agric. Biol., 8: 641-644.

Aboulhassan, M.A., S. Souabi, A. Yaacoubi, and M. Baudu. 2006. Removal of surfactant from industrial wastewaters by coagulation flocculation process. Int. J. Environ. Sci. Technol., 3(4): 327-332. https://doi. org/10.1007/BF03325941

Afzal, M., G. Shabir, S. Iqbal, T. Mustafa, Q.M. Khan and Z.M. Khalid. 2014. Assessment of heavy metal contamination in soil and groundwater at leather industrial area of Kasur, Pakistan. CLEAN-Soil Air Water, 42(8):11331139. https://doi.org/10.1002/clen.201100715

Ali, H., E. Khan and I. Ilahi. 2019. Environmental chemistry and ecotoxicology of hazardous heavy metals: environmental persistence, toxicity, and bioaccumulation. J. Chem., 2019. https://doi. org/10.1155/2019/6730305

Ajmal, M. and A.U. Khan. 1985. Effects of a textile factory effluent on soil and crop plants. Environ. Pollut. A. Ecol. Biol., 37(2): 131-148.https:// 
doi.org/10.1016/0143-1471(85)90004-2

Ekeanyanwu, C.L., C.S. Alisi and R.C. Ekeanyanwu. 2020. Levels of Aflatoxin M1 and selected heavy metals $(\mathrm{Pb}, \mathrm{Cd}, \mathrm{Cr}, \mathrm{Cu}, \mathrm{Zn}$, $\mathrm{Fe}, \mathrm{As}$, and $\mathrm{Hg}$ ) in the breast milk of lactating mothers in South Eastern, Nigeria. Food Contr., 112: 107150. https://doi.org/10.1016/j. foodcont.2020.107150

Delves, H.T., G. Shepherd and P. Vinter. 1971. Determination of eleven metals in small samples of blood by sequential solvent extraction and atomic-absorption spectrophotometry. Analyst, 96(1141): 260273. https://doi.org/10.1039/an9719600260

Gunatilake, S.K., 2015. Methods of removing heavy metals from industrial wastewater. Methods, 1(1): 14 .

Iqbal, Z., F. Abbas, M. Ibrahim, T.I. Qureshi, M. Gul and A. Mahmood. 2020. Human health risk assessment of heavy metals in raw milk of buffalo feeding at wastewater-irrigated agricultural farms in Pakistan. Environ. Sci. Pollut. Res., 27(23): 29567-29579. https://doi. org/10.1007/s11356-020-09256-4

Jaishankar, M., T. Tseten, N. Anbalagan, B.B. Mathew and K.N. Beeregowda. 2014. Toxicity, mechanism and health effects of some heavy metals. Interdiscip. Toxicol., 7(2): 60. https:// doi.org/10.2478/intox-2014-0009

Jumbe, A.S. and N. Nandini. 2009. Heavy metals assessment of wetlands around peenya industrial area, Bangalore, India. J. Res. Environ. Life Sci., 2: 25-30.

Khan, K., Y. Lu, H. Khan, S. Zakir, S. Khan, A.A. Khan, L. Wei and T. Wang. 2013. Health risks associated with heavy metals in the drinking water of Swat, northern Pakistan. J. Environ. Sci., 25(10): 2003-2013. https://doi. org/10.1016/S1001-0742(12)60275-7

Khan, S., Q. Cao, Y.M. Zheng, Y.Z. Huang and Y.G. Zhu, 2008. Health risks of heavy metals in contaminated soils and food crops irrigated with wastewater in Beijing, China. Environ. Pollut., 152(3): 686-692. https://doi. org/10.1016/j.envpol.2007.06.056

Lakherwal, D., 2014. Adsorption of heavy metals: A review. Int. J. Environ. Res., 4(1): 41-48.

Li, C., Zhou, K. Qin, W. Tian, C. Qi, M. Yan, X. and W. Han. 2019. A review on heavy metals contamination in soil: Effects, sources, and remediation techniques. Soil Sediment
Contam., 28(4): 380-394. https://doi.org/10.1 080/15320383.2019.1592108

Mahfooz, Y., A. Yasar, M.T. Sohail, A.B. Tabinda, R. Rasheed, S. Irshad and B. Yousaf. 2019. Investigating the drinking and surface water quality and associated health risks in a semiarid multi-industrial metropolis (Faisalabad), Pakistan. Environ. Sci. Pollut. Res., 26(20): 20853-20865. https://doi.org/10.1007/s11356019-05367-9

Olugbuyiro, J. 2011. Physico-chemical characteristics of industrial effluents in Lagos state, Nigeria. Global J. Pure Applied Sci. Technol., 1: 49-54.

Ouyang, Z., Z. Yang, G. Feng, and Y.Zhao. 2019. Analysis on enrichment of aquatic plants response to different heavy metal ions in polluted water taking duckweed as an example. Appl. Ecol. Environ. Res., 17: 3469-3482.

United States. Environmental Protection Agency. Office of Wastewater Management, 1995. A guide to the biosolids risk assessments for the EPA Part 503 rule. US Environmental Protection Agency, Office of Wastewater Management.

Manoj, K., P.K. Padhy and S. Chaudhury. 2012. Study of heavy metal contamination of the river water through index analysis approach and environmetrics. Bull. Environ. Pharmacol. Life Sci., 1(10): 7-15.

World Health Organization, 1993. Guidelines for drinking-water quality. World Health Organization.

Rahman, Z. and V.P. Singh. 2019. The relative impact of toxic heavy metals (THMs) (arsenic (As), cadmium (Cd), chromium $(\mathrm{Cr})(\mathrm{VI})$, mercury $(\mathrm{Hg})$, and lead $(\mathrm{Pb}))$ on the total environment: An overview. Environ. Monit. Assess., 191(7): 1-21. https://doi.org/10.1007/ s10661-019-7528-7

Shah, N., F. Abbas, Y. Abbas, S.A. Haider, Q. Khan, N. Asghar, S. Noor, S.N. Abbas, Ali, N. and A. Ali. 2015. Assessment of the workplace conditions and health and safety situation in chemical and textile industries of Pakistan. Scien. J. Public Health, 3(6): 862-869.https:// doi.org/10.11648/j.sjph.20150306.20

Shakoor, S.A.B. and M.A. Farooq. 2013. Effects of irrigation with waste water from different industries on vegetables grown in vicinity of Faisalabad, Pakistan. 
Shu, D., Y. He, Yue, H. and Q. Wang. 2015. Microbial structures and community functions of anaerobic sludge in six full-scale wastewater treatment plants as revealed by 454 highthroughput pyrosequencing. Bioresource. technol., 186:163-172.

Sharma, A., J.K. Katnoria and A.K. Nagpal. 2016. Heavy metals in vegetables: Screening health risks involved in cultivation along wastewater drain and irrigating with wastewater. Springer Plus, 5(1): 1-16. https://doi.org/10.1186/ s40064-016-2129-1

Simeonov, L.I., M.V. Kochubovski and B.G. Simeonova. 2010. Environmental heavy metal pollution and effects on child mental development: Risk assessment and prevention strategies. Springer. https://doi. org/10.1007/978-94-007-0253-0

Simonetti, V.C., D. Frascareli, E.S. Gontijo, D.S. Melo, K. Friese, D.C. Silva and A.H. Rosa. 2019. Water quality indices as a tool for evaluating water quality and effects of land use in a tropical catchment. Int. J. River Basin Manage., 1-12. https://doi.org/10.1080/15715 124.2019.1672706

Tepanosyan, G., L. Sahakyan, O. Belyaeva, N. Maghakyan and A. Saghatelyan. 2017.
Human health risk assessment and riskiest heavy metal origin identification in urban soils of Yerevan, Armenia. Chemosphere, 184: 1230-1240. https://doi.org/10.1016/j. chemosphere.2017.06.108

Titilawo, Y., A. Adeniji, M. Adeniyi and A. Okoh. 2018. Determination of levels of some metal contaminants in the freshwater environments of Osun State, Southwest Nigeria: A risk assessment approach to predict health threat. Chemosphere, 211: 834-843. https:// doi.org/10.1016/j.chemosphere.2018.07.203

Yi, Y., Z. Yang and S. Zhang. 2011. Ecological risk assessment of heavy metals in sediment and human health risk assessment of heavy metals in fishes in the middle and lower reaches of the Yangtze River basin. Environ. Pollut., 159(10): 2575-2585. https://doi.org/10.1016/j. envpol.2011.06.011

Yousaf, B. G. Liu, R. Wang, M. Zia-ur-Rehman, M.S. Rizwan, G.I. Murtaza and A. Shakoor. 2016. Investigating the potential influence of biochar and traditional organic amendments on the bioavailability and transfer of $\mathrm{Cd}$ in the soil-plant system. Environ. Earth Sci., 75(5): 374. https://doi.org/10.1007/s12665-016$5285-2$ 